\title{
Review on Organic Fertilizer and Its Roles in Sustaining Soil Fertility in Ethiopia
}

\author{
Gemechu Chali* Dula Genati** \\ Ethiopian Institute of Agricultural Research, Jimma Agricultural Research Center, \\ P.O. Box 192, Jimma, Ethiopia
}

\begin{abstract}
Organic fertilizers increase the quality and yield of agricultural crops in ways similar to inorganic fertilizers. As the price of synthetic fertilizers continues to increase, manure is becoming a more valuable and less expensive source of nitrogen fertilizer. Crop producers are increasingly buying manure from livestock producers or adding livestock to their crop operations so that they can incorporate manure into their practices. On-manufactured nitrogen fertilizers are increasingly being used as a means to reduce vulnerability to the price changes in fossil fuels. The most common alternatives to non manufactured nitrogen fertilizers identified include green manures and integrating livestock into crop production. These practices, combined with other techniques such as conservation tillage, have shown to greatly decrease the need for synthetic fertilizers by increasing nutrient efficiency and improving soil health. Organic nutrient source improves the physical, chemical and biological quality of soil besides providing both macro and micro nutrients to crops. The improvement in qualities include improvement in soil structure, water holding capacity, electrical conductivity, bulk density, lesser soil erosion, preventing the leaching of nutrients and provide nutrients to soil micro flora.
\end{abstract}

Keywords: Compost, Organic fertilizer; Vermicompost

DOI: $10.7176 / \mathrm{JNSR} / 12-4-02$

Publication date: February $28^{\text {th }} 2021$

\section{Introduction}

The role of organic materials as nutrient sources is the biological processes of decomposition, which involve the biochemical breakdown of dead organic tissue into its inorganic constituent forms, primarily through the action of microorganisms. The process by which essential nutrient elements in unavailable organic forms are converted into their inorganic forms that are available for use by growing plant is known as mineralization. It is during decomposition of organic materials in soils that SOM is formed and nutrients are released. SOM can therefore said to be made up of organic materials of diverse origin that are at various stages of decomposition through the action of soil microorganisms (14).

More recently (29) have argued that the microbial population of soil can adapt to any quality or composition of soil organic material, so that even organic materials high in lignin and aromatics can be decomposed rapidly if the appropriate population of microorganisms is present. Traditionally, organic materials high in lignin and aromatics were considered to be resistant and to have a high residence time. The implication is that the microbial processes such as nutrient cycling in soils can be managed by manipulating the soil microbial populations. Organic matter has long been seen as an important component of soils. Many soil scientists and geologists consider that it is the influence of organic matter and biological activity that distinguishes soil from the underlying rock and parent material (26). The increase in OM content of the soil due to compost decreases the level of compaction, decreasing bulk density to more favorable level. Who found decrease in soil bulk density as a result of continuous application of Farm yard manure. Bulk density was not affected in the application of mineral fertilizer only due to the decrease in OC and OM as result of decomposition over time (33).

The present investigation on composting and vermicomposting using cow dung and microbial inoculums prove that the waste converted to nutrient rich compost and Vermicompost. To compost, the organic material that has been generated is gathered and treated in a way which hastens its biological decomposition. Vermicomposting (worm bin composition) uses red worms in an enclosed container to convert vegetable and fruit scraps into a nutrient-rich soil amendment called worm castings. Compost is increasingly being applied to agricultural and forest lands that have been depleted of their organic matter. The most common use of compost today is probably in topsoil mixes used in the landscape industry (9). Fertilizers are used to improve soil fertility but intensive inorganic fertilizer usage in agriculture causes so many health problems and unrecoverable environmental pollution. Thus, to reduce and eliminate the adverse effects of Synthetic fertilizers on human health and environment, now-a-days a new agricultural practice have been developed called as organic agriculture, sustainable agriculture or ecological agriculture $(\mathbf{2}, \mathbf{1 0})$.

Organic farming is a specific crop system that relies only on organic fertilizers. Some constraints in the organic fertilizers sector derive from their legal definitions and the establishment of clear quality standards, which are particularly important for trade at global level. This holds true also for a specific group of products that are defined as bio-stimulants or growth enhancers, metabolic enhancers (1). Nevertheless, the continuous 
development of new processing technologies, particularly for the treatment of organic wastes, is further opening new possibilities to produce new organic fertilizers. Crop plants require nitrogen, phosphorous and potassium to maintain normal physiological function of the cell. In similar way according to (19) lack of nitrogen results in poor growth and slow growth, but the excess use of nitrogen results in delayed maturity and low quality of leaf.

\section{Discussion}

\subsection{History of organic nutrients in soil}

Several factors contribute to reducing the fertility status and quality of soil in Ethiopia. Limited use of crop residue and animal dung and little or no use of modern technologies to restore soil fertility, high price of mineral fertilizer and low use of organic nutrient sources (30).Organic nutrient source improves the physical, chemical and biological quality of soil besides providing both macro and micro nutrients to crops. The improvement in qualities include improvement in soil structure, water holding capacity, electrical conductivity, bulk density, lesser soil erosion, preventing the leaching of nutrients and provide nutrients to soil micro flora (13). Applying organic materials over several seasons results in increased yields, because the tannin and lignin content slows their decomposition and has a long-term effect on nutrient availability and also reported an increase in maize grain yield when low doses of $\mathrm{N}$ and $\mathrm{P}$ fertilizers were applied with different organic materials such as farmyard and compost, as compared with the control treatment. The combined use of organic materials and $\mathrm{N}$ and $\mathrm{P}$ fertilizers gave similar grain yield when compared to the recommended rate of $\mathrm{N}$ and $\mathrm{P}$ fertilizers $(110 / 20 \mathrm{~kg} / \mathrm{ha})$ (21).

Many researchers reported that in an organically managed field activity of earth worm is higher than in inorganic agriculture. In the biodegradation process earthworms and microbes work together and produce Vermicompost, which is the worm fecal matter with worm casts. Vermicompost provided macro elements such as $\mathrm{N}, \mathrm{P}, \mathrm{K}, \mathrm{Ca}, \mathrm{Mg}$ and microelements such as $\mathrm{Fe}, \mathrm{Mo}, \mathrm{Zn}$, and $\mathrm{Cu}$ (17). Compost application to agricultural land needs to be carried out in a manner that ensures sustainable development and also Management systems have to be developed to enable to maximize agronomics benefit, whilst ensuring the protection of environmental quality. The main determinant for efficient agronomics use is nitrogen availability, high nitrogen utilization in agriculture from mineral fertilizers is well established and understood, whereas increasing the nitrogen use efficiency of organic fertilizers requires further investigation (3).Plant wastes such as wood ash, spent grain, rice bran, and sawdust were effective as fertilizers. Fuel wood constitutes up to $61-86 \%$ of the primary energy consumption in many African regions, from which ash residues are generated (4).

The chemical and physical properties of ash depend on the contents of the combusted material (type of plant and which plant parts) and the burning process (example temperature) but also on the conditions of collection and storage $(\mathbf{1 2}, \mathbf{2 3}$, and 24). However, it is a significant source of a number of plant nutrients including $P, K$, $\mathrm{Mg}$ and $\mathrm{Ca}$ together with a number of micronutrients (6). It also has properties resembling those of lime. Thus, applying ash to agricultural fields can compensate for nutrient losses caused by harvesting and leaching and counteract soil acidification $(\mathbf{2 5}, \mathbf{2 2})$.

\subsection{Properties of organic fertilizers}

Organic nutrient sources are highly heterogeneous and vary in quality and quantity. The quality aspect is important in determining the nutrient release potential of the organic fertilizers. Microorganisms that decompose organic fertilizers use the carbon in such materials as an energy source for growth. Required in even bigger quantities by microorganisms for growth and reproduction is nitrogen $(\mathrm{N})$. Commonly available materials are often particularly low in $\mathrm{N}$ content. For organic fertilizers with low $\mathrm{N}$ contents (such as cereal straw and most small holder farm yard manures), microorganisms themselves will consume much of the available $\mathrm{N}$ for their own growth, consequently, insignificant amounts of $\mathrm{N}$ will be released for the crop(26). Organic fertilizers are derived from biological or living materials. These fertilizers take longer time to release the nutrient in the soil. In contrast, inorganic fertilizers are classified as those fertilizers that are synthesized artificially or mined from nonliving materials. Organic fertilizers come in the different forms such as: manure derived from livestock such as cows, chickens, goats and others and Green manure which are obtained from young plants, especially different type of legumes (26).

\subsubsection{Advantages of organic fertilizers}

Organic farming is one of the fastest growing sectors of the agriculture worldwide and its main objective is to create a balance between the inter-connected system such as soil organism, plants, animals and humans. The organic fertilizers offer the biological process necessities of plants and conjointly suppress the plant pests' populations (6, 15 and 16). Additionally, they increase the microorganism activity in soil, anion and cation exchange capability, organic matter and carbon-content of soil. Organic fertilizers increase the quality and yield of agricultural crops in ways similar to inorganic fertilizers (6) however; it does not cause environmental pollution water retention and resistance to erosion.

Organic fertilizers provide nitrogen in a usable form, which will help plant to improve plant growth while at 
the same time neither cause burning of roots nor destroying beneficial micro-organisms in the soil. Organic fertilizers help to prevent diseases by meeting the plants "nutritional needs and enhancing plant tolerance. This action removes a serious source of stress. Plant wastes such as wood ash, spent grain, rice bran, and saw dust were effective as fertilizers, According to (5).

\subsubsection{Major limitations of organic fertilizers}

Generally require large amounts to have desired effects, Extra investment in labor for harvesting (green manures) and preparation (cattle manure), Unavailability of seed for green manures is one of the major limitations, Quality for most has to be enhanced by combining with expensive mineral fertilizers, Green manures must occupy land at a time when other food crops could be grown (5).

\subsection{Compost}

Composting is the decomposition of organic wastes in the presence of oxygen (air); products from this process include $\mathrm{CO} 2, \mathrm{NH} 3$, water and heat. This can be used to treat any type of organic waste but, effective composting requires the right blend of ingredients and conditions. These include moisture contents of around $60-70 \%$ and carbon to nitrogen ratios $(\mathrm{C} / \mathrm{N})$ of $30 / 1$. Any significant variation inhibits the degradation process. Generally wood and paper provide a significant source of carbon while sewage sludge and food waste provide nitrogen. To ensure an adequate supply of oxygen throughout, ventilation of the waste, either forced or passive is essential. Compost improves soil structure, increases the amount of organic matter, and provides nutrients. Biodegradation is the means by which organic matter is recycled in its environment. Compost is also used as a seed starting medium generally mixed with a small portion of sand for improved drainage (34).To achieve a good composting process, an initial $\mathrm{C}: \mathrm{N}$ ratio of between $25: 1$ and 40:1 must exist for the initial matrices. This condition, together with a well aerating system, assures that a temperature between $55^{\circ} \mathrm{C}$ and $80^{\circ} \mathrm{C}$ is reached for a period of at least 15 days, which ensures the stabilization of the product and reduction of pathogen population (35).All living organisms are made up of large amounts of the element carbon (C) combined with smaller amounts of nitrogen $(\mathrm{N})$. The balance of these elements in a material is called the carbon-to-nitrogen ratio $(\mathrm{C}: \mathrm{N})$. This ratio is an important factor in determining how easily bacteria can decompose an organic waste (Table1).

Table 1. Average Carbon: Nitrogen Ratios for Organic Materials (19)

\begin{tabular}{|l|l|}
\hline High Nitrogen Materials: & C:N \\
\hline Grass Clippings & $19: 1$ \\
\hline Sewage Sludge (digested) & $16: 1$ \\
\hline Food Wastes & $15: 1$ \\
\hline Cow Manure & $20: 1$ \\
\hline Horse Manure & $25: 1$ \\
\hline High Carbon Materials: & $\mathbf{C : N}$ \\
\hline Leaves and Foliage & $40-80: 1$ \\
\hline Bark & $100-130: 1$ \\
\hline Paper & $170: 1$ \\
\hline Wood and Sawdust & $300-700$ \\
\hline
\end{tabular}

Composting farm manure is an excellent method to stabilize its nutrient content and to reduce many of the drawbacks associated with raw manure use (Table 2). A good compost of animal by-products is a safe fertilizer due to the low content in soluble salts, the minimal load of plant and pathogens, the slower release of its nutrients, and the higher content of humus fractions (11).

The step to do compost first pit layer of residues spread on the surface bottom about $20 \mathrm{~cm}$ then next ash sprinkler water next FYM spread a good amount of manure 3-5 full spade square meter /layer will be enough some soil should be spread few spade then repeat all step until reach pit of $2 \mathrm{~m}$ wide $4 \mathrm{~m}$ length to improve aeration bamboo stick placed standing in the middle cover the pit with dry grass or leaf and never dry or wet. After a month turn all compost to second pit and compost mature. Mature compost show good uniformity in color (black) and in texture light in weight and spongy appearance (32).

To make compost Avoid trees and shrubs that may push their roots up into the pile give some thought to both convenience and appearance when choosing a location. Woody or "brown" yard wastes, like tree trimmings and autumn leaves, can be shredded and used as mulch around plants and on paths. Eventually they'll return to the soil. Food wastes, as well as green yard wastes like grass clippings, can be dug into the ground. Use largerscale "soil incorporation" only where you won't be planting for a few months. Retain heat a little longer in the fall by covering the pile and insulating the container, perhaps with bags of leaves. Increasing the amount of green material or using a compost activator may help keep the temperature up. Keep adding to the compost through the winter: it may not seem to be doing much, but the frozen materials will quickly finish breaking down when spring comes. A perfectly good compost pile can be built out of nothing fancier than leaves and grass clippings. However, most compost is naturally close to a neutral $\mathrm{pH}$ by the time it is ready for use . When an 
active compost pile fails to heat up once more, and very little of the original material can be recognized, the com-post is ready to use. It will be the rich brown color of good soil and smell something like the humus of a forest floor (20).

\subsubsection{Advantages of compost}

Lower water content: greater total concentration of nutrients than manure on wet basis, adds OM that releases nutrients slowly, High OM content improves soil structure, increases CEC and water holding capacity, Greater water holding capacity may decrease irrigation needs and reduce pumping costs and Beneficial microbes in compost increase nutrient cycling and can suppress soil and foliar pathogens (34).

\subsubsection{Disadvantages of compost}

Making compost involves costly equipment, planning, monitoring and time to produce, nutrient enriched leachates must be controlled to prevent runoff or ground water contamination and not fast nutrient releasing (34).

\subsubsection{Composting materials}

Top soils, Green vegetables, Ash, Animal dung, Dry vegetables, Stalks and Banana leaf covering. Microorganisms involved in composting are: Fungi, Actinomycetes, Bacteria, Protozoa's raw manure and half finished compost also have a reputation for 'burning' plant roots. This is as a result of the heat generated during the decomposition process. This killing also extends to many of the soil organisms that cannot endure the thermophilic(high heat) condition.OM in composts can compete with $\mathrm{P}$ fertilizers for reactions with soil miner high OM content improves soil structure, increases CEC and water holding capacity (26).

\subsection{Vermicompost}

Vermicompost is a type of compost produced using worms as a composter. It is the process by which worms are used to convert organic materials (usually wastes) into a humus-like .The system contains:-A physical structure: a worm box or container, Biological organisms: the worms and micro-organisms and controlled environment: temperature, moisture, acidity. A maintenance program: bedding preparation, food waste burying, separating the worms from compost and using compost material (18). Another method of composting manure as well as other materials of animal and plant origin is utilizing various species of worms, specifically brandling worms (Eisenia foetida) and red worms or red wigglers (Lumbricus rubellus). The result of this process is a Vermicompost, a product that can be further processed to obtain extracts. Passing through the gut of the earthworm, recycled organic wastes are excreted as castings, or worm manure, an organic material rich in nutrients that looks like fine-textured soil. Secretions in the intestinal tracts of earthworms, along with soil passing through the earthworms, make nutrients more concentrated and available for plant uptake.

Commercial producers of Vermicompost normally are using dairy cow or pig manure, sewage sludge, agricultural waste, food processing and grocery waste, cafeteria waste, grass clippings and wood chips. Green waste should be added in moderation to avoid excessive heating, while meat waste and dairy products are likely to putrefy and therefore are not utilized. The $\mathrm{pH}$, nutrient, and microbial content of these fertilizers vary upon the inputs fed to worms. Pulverized limestone or calcium carbonate can be added to the system to basify the $\mathrm{pH}$. Avoid Animal products, such as meat, bones, meat that may attract pests bur earth worms eat all kinds of food and yard wastes vegetable and fruit waste. If these waste by-products are not utilized or treated properly they could pose serious environmental problems threatening the sustainability of this production sector. Ways to harvesting way involves moving the finished compost \&worms over to one side of a bin and adding new bedding material and food waste to the other side. Worms in the finished compost should move over to the new bedding with the fresh wood waste. However, they can be considered as possible raw materials in the production of organic fertilizers (31).

Table 2: Average chemical characteristics of Vermicompost adapted from (Tahiri and Guardia, 2009).

\begin{tabular}{|l|c|}
\hline Parameter & Average content \\
\hline Total N\% & $1.9-2.5$ \\
\hline $\mathrm{N}-$ nitrate $(\mathrm{ppm})$ & $900-1000$ \\
\hline $\mathrm{P} \%$ & $0.4-0.6$ \\
\hline $\mathrm{K} \%$ & $0.7-0.9$ \\
\hline $\mathrm{Ca} \%$ & $4.4-4.6$ \\
\hline $\mathrm{Mg} \%$ & $0.4-0.6$ \\
\hline $\mathrm{pH}$ & $6.8-7.0$ \\
\hline $\mathrm{EC}(\mathrm{mmhos} / \mathrm{cm})$ & $11-1$ \\
\hline
\end{tabular}

The nutrient content of the compost varies according to the materials utilized for the preparation of the initial mass.

\subsection{Organic Matter, Cover Crops, and Green Manures}

Soil organic matter and humus have been found to create a healthy and fertile soil structure. Most soils in 
Colorado have low amounts of organic matter, containing less than 1.5 percent Soils containing higher percentages of organic matter or humus are better able to retain water and nutrients and resist erosion. Cover crops and green manures can serve as organic material sources for agricultural systems, helping to decrease the potential for soil erosion while improving soil tilth, water-holding capacity, stability, and structure. A cover crop is any crop that is grown to provide soil cover mainly for the purpose of reducing wind and water erosion. A green manure is any field or forage crop, including a cover crop, that is incorporated into the soil while the crop is still green or flowering. Cover crops and green manures can be annual, biennial, or perennial plants that grow in a pure or mixed stand during all or part of the year. In addition to providing ground cover they may also help suppress weeds and reduce diseases and insect pests (28).

\section{Conclusion}

use of organic fertilizers are eco-friendly and has got an upper edge as compared to inorganic fertilizers which causes environment pollution and also might get accumulated in the soil leading to human health hazards. As done earlier with chemical fertilizers, for organic fertilizers also, bio fertilization programs, organic fertilizer like composting and vermicomposting work should be encouraged in our country having recommended type and dose of fertilizers most suited for the varied crop growth stages of the crop, should be implemented. Also research in Organic farming will be increase considerably in the developing countries, but there is still a need for targeted research activities to help promote and develop organic farming. Train those who are the user of organic fertilizer needed by the help of who have good skill and knowledge of organic fertilizer especially in our country Ethiopia. So basic that everyone can understand its underlined meaning; a better and healthier future today is a better and healthier future tomorrow.

\section{Reference}

1. Aboudrare .A., 2009. Agronomy Durable Principles at Critiques. Rapport de Formation Continue. FAO 2009, pp 49.

2. Aksoy U., 2001. Ecological Farming Symposium in Turkey. 14-16 December.

3. Amlinger, F. Götz, B. Dreher, P.Geszti, J. and Westerner, C., 2003. Nitrogen in bio waste and yard waste compost: dynamics of mobilization and availability a review. European Journal of Soil Biology 39, 107-116.

4. Amous .S., 1999. The role of wood energy in Africa. In: Rivero, S.I. (ed.) Wood energy today and tomorrow. Forestry Department, Food and Agriculture Organization of the United Nations. Assessment of safety and efficiency of nitrogen organic fertilizers from animal-based protein hydrolytes-a laboratory multidisciplinary approach. J. Sci. Food Agric.6239.

5. Ayoub, A.T. (1999). Fertilizers and the environment.Nutrient Cycling in Agroecosystems55: 117-121.

6. Berova M, G Karanatsidis, K Sapundzhieva and V. Nikolova, 2010. Effect of organic fertilization on growth and yield of pepper plants (Capsicum annuum L.). Folia Horticulture Ann. 22: pp 3-7.

7. Bougnom, B.P., Knapp, B.A., Etoa, F-X. and Insam, H., 2011.Possible use of wood ash and compost for improving acid tropical soils. In: Insam, H., and Knapp B.A (eds).Recycling of biomass ashes. SpringerVerlag, Berlin Heidelberg. Pp. $87-105$.

8. Bulluck LR, Brosius M, Evanylo GK, and Ristaino J.B., 2002. Organic and synthetic fertility amendments influence soil microbial, Physical and chemical properties on organic and conventional farms. Appl. Soil Ecol. 19 (2): pp 147-160.

9. California Integrated Waste Management Board, 2005. Critters in Your Pile.

10. Chowdhury. R, 2004. Effects of chemical fertilizers on the surrounding environment and the Alternative to the chemical fertilizers IES- Envis News letter. (3) pp 4-5.

11. De Bertoldi, M., Sequi, P., Lemmes, B. and Papi, T. eds., 1996. The Science of Composting, Parts 1 and 2. New York, NY: Blackie Academic and Professional.

12. Demeyer, A., Voundi Nkana, J.C. and Verloo, M.G., 2001. Characteristics of wood ash and influence on soil properties and nutrient uptake: an overview. Bio resource Technology. 77, pp. $287-295$.

13. Fentaw Ejigu, 2010. Bio-slurry in Ethiopia: what is it and how to use it, Institute for Sustainable Development (ISD) and National Biogas Program Ethiopia Coordination Office, Addis Ababa, Ethiopia.

14. Fairhurst, T. (ed.), 2012. Handbook for Integrated Soil Fertility Management. Africa Soil Health Consortium, Nairobi pp.31.

15. Heeb A, Lundegardh B, Ericsson T, and Savage G.P,2005a. Effects of nitrate- ammonium- and organicnitrogen-based fertilizers on growth and yield of tomatoes. J. Plant Nut. Soil Sci.,168(1): pp123-129.

16. Heeb A, Lundegardh B, Ericsson T, and Savage G.P, 2005. Nitrogen form affects yield and taste of tomatoes J. Sci. Food Agric.85: pp 1405-1414.

17. International Journal of Agronomy,2013. A Review of Organic Farming for Sustainable Agriculture in Northern India. Article ID 718145,8 p.

18. K. Amir and I. Fouzia, 2011. Chemical nutrient analysis of different composts (Vermicompost and Pit 
compost) and their effect on the growth of a vegetative crop Pisum sativum," Asian Journal of Plant Science and Research, vol. 1, no. 1, pp. 116-130.

19. Mani J, 2002. Early events in environmental stresses in plants: Induction mechanisms of oxidative stress. In: D. Inzè and M.V. Montague (eds.) Oxidative stress in plants. Taylor and Francis, New York. pp 217-246.

20. Master Recycler Program ,2018. New Brunswick Department of the Environment, "Black Magic, the Composting Handbook.

21. Negassa W; Kefalew Negisho; Friesen DK; Ransom J; Abebe Yadessa. 2004. Determination of optimum Farmyard manure and NP fertilizers for maize on farmer's fields. pp 387-393. In: Friesen DK and Palmer AFE. (eds.). Integrated Approaches to higher maize productivity in the new millennium: Proceedings of the Seventh Eastern and Southern African Regional Maize Conference,5-11 February 2001, Nairobi, Kenya: CIMMYT.

22. Nkana, J.C.V., Demeyer, A., Verloo, M.G., 1998.Chemical effects of wood ash on plant growth in tropical acid soils. Bio-resource Technology. Vol. 63, pp. $251-260$.

23. Perkiömäki, J., Levula, T. and Fritze, H., 2004. A reciprocal decomposition experiment of Scots pine needles 19 yr after wood ash fertilization. Soil Biology and Biochemistry. Vol. 26,pp. $731-734$.

24. Pitman, R.M., 2006. Wood ash use in forestry - a review of environmental impacts. Forestry. Vol.79, pp. 563 $-588$.

25. Saarsalmi, A., Kukkola, M., Moilanen, M. and Arola, M, 2006. Long-term effects of ash and N fertilization on stand growth, tree nutrient status and soil chemistry in a Scots pine stand. Forest ecology and Management. Vol. 235, pp. $116-128$.

26. Solomon, WGO, RW Ndana, and Y Abdulrahim, 2012. The Comparative study of the effect of organic manure cow dung and inorganic fertilizer NPK on the growth rate of maize (Zea mays L.). International Research Journal of Agricultural Science and Soil Science. 2: pp.516-519.

27. Soil Survey Staff, 2010. Keys to Soil Taxonomy. (Eleventh Edition). US Department of Agriculture. Natural Resources Conservation Service. US Government, Washington DC.

28. Sulivan, Preston ,2003. Overview of Cover Crops and Green Manures.” National Sustainable Agriculture Information Service. Published.

29. Schmidt, MW, Torn, MS, Abiven, S, Dittmar, T, Guggenberger, G, Janssens, IA, Kleber, M, KogelKnabner, I, Lehmann, J, Manning, DAC, Nannipieri, P, Rasse, DP, Weiner, S and Trumbore, 2011. Persistence of soil organic matter as an ecosystem property. Nature, 478, $49-56$.

30. Taye Belachew and Yifru Abera, 2010. Assessment of Soil Fertility Status with Depth in Wheat Growing Highlands of Southeast Ethiopia, World Journal of Agricultural Sciences 6: 525-531.

31. Tahiri, S. and Guardia, M.D.L., 2009. Treatment and valorization of leather industry solid wastes: A review. J. Am. Leather Chem. Assoc., 104: 52-67.

32. Rodale book of composting, 1982.Rodale press,Emmanus ,Pennysylvania.278p.

33. Wondimu Bayu, Rethman G., Hammes S. and Getachew Alemu, 2006. Application of Farmyard Manure Improved the Chemical and Physical Properties of the Soil in a Semi-Arid Area in Ethiopia. Biological Agriculture and Horticulture, 24: 293-300.

34. Yvette B. Guanzon, and Robert J. Holmer, 2000.Composting of Organic Wastes: A Main Component for Successful Integrated Solid Waste Management in Philippine Cities.

35. Zucconi, F., Monaco, A., Forte, M. and De Bertoldi, M., 1981. Evaluating toxicity of immature compost. Bio-cycle, 22: 54-7. 